with about sixteen lines of uniform discal cilia where broadest. Fore wing with only about two short lines of coarse cilia proximad of hairless line. Whole body scaly reticulate. A very short, delicate carina between the axillæ. Scutellum more finely scaly than the scutum. Ovipositor not prominent.

The male is similar to the female but the scutellum is scaly like the rest of the thorax, the funicle joints all somewhat longer, subquadrate, the club shorter; the third tooth of the mandible is longer, the other shorter. Wings hyaline.

Described from a male and a large number of females labelled "From an Euxoa larva, Queensboro, Ontario. A. Gibson;" also "from larva of Hadena devastatrix, Ottawa, Canada, July 12, 1914. A. Gibson." Types: Catalogue No. 19318, U. S. N. M., 8 females on five tags (seven paratypes).

Differs from the typical form in having the fore wings narrower and the venation black; both forms bear a rectangular fuscous patch along the stigmal vein. Type locality, Ottawa.

Berecyntus bakeri Howard var. arizonensis var. nov.

Female: Differs from bakeri bakeri in having the fore wings distinctly more dusky, infuscated throughout from the bend of the submarginal vein.

Iescribed from four females from Phoenix, Ariz., March 20, 1915. From Choraxagrotis species. H. O. Marsh, Chtn. No. 978. Types: Catalogue No.19319, U.S. N. M., the above specimens on separate tags; three paratypes, one type.

\title{
THREE NEW NORTH AMERICAN SPECIES OF THE GENUS AGROMYZA (DIPTERA).
}

\author{
By J. R. Malloch, \\ Urbana, Ill.
}

Herewith are presented descriptions of three undescribed species of Agromyza from Illinois. The type specimens are deposited in the collection of the Illinois State Laboratory of Natural History.

This paper is published by permission of Dr. Stephen A. Forbes, State Entomologist of Illinois. 
Agromyza subangulata sp. nov.

Male: Black. Head black, only the apex of proboscis yellow; frons opaque, brown-black, orbits subshining; lunule whitish pollinose. Thorax shining black, disc of mesonotum distinctly brownish pollinose, central vertical suture and upper margin of pleuræ from wing base nearly to anterior extremity narrowly lemon-yellow; roots of wings lemon-yellow; scutellum concolorous with disc of mesonotum. Abdomen unicolorous glossy black. Legs black; fore knees and bases of tarsi yellowish. Wings clear, bases of thick veins lemon-yellow, remainder brown. Squamæ pale yellow, fringe concolorous. Halteres pale yellow.

Frons more than a third the width of head; orbits distinct, each at widest part about half as wide as is center stripe at same part; five orbital bristles present, which are of moderate length, slightly decreasing anteriorly, the anterior two pairs incurved; orbital hairs sparse; antennæ small, third joint disc-like, slightly pilose; arista bare, tapering, its length about one third more than anterior width of frons; face very slightly receding below; cheek very narrow, at middle about one eighth as high as eye, the latter about one and a third times as high as long; marginal hairs not very numerous, but distinct, vibrissa moderately differentiated. Mesonotum with four pairs of dorso-central bristles; discal setulæ rather long and hairlike, about eight rows between the anterior dorso-centrals; the pair of bristles between the posterior dorso-centrals hardly distinguishable from the discal setulæ. Abdomen ovate; surface with many setulose hairs; hypopygium of normal size. Legs normal; mid tibiæ with the posterior bristles small. Wing with costa to end of fourth vein; veins 3 and 4 distinctly divergent at apices, reaching wing margin at about equal distances before and behind wing tip respectively; inner cross-vein in vertical line with apex of first vein, and distinctly beyond middle of discal cell; outer cross-vein distant its own length from inner; last section of fourth vein four times as long as penultimate section; last section of fifth subequal with the preceding section; auxiliary indistinct but complete; sixth vein reaching three fourths of distance to wing margin. Length, $2.5 \mathrm{~mm}$.

Type locality, St. Joseph, Ill., May 3, 1914 (Hart and Malloch). Food plant unknown. 
This species will "run down" to angulata Loew in my table of species in this genus, ${ }^{1}$ but may be readily separated from it by the characters of the wing venation.

\section{Agromyza albidohalterata sp. nov.}

Male: Black, shining. Frons with center stripe reddish yellow, ocellar region, and orbits except their lower portions black; antennæ reddish yellow; arista brown; face and cheeks grayish yellow, the former slightly blackened on center and mouth margin; proboscis yellow; palpi brownish; back of head black. Thorax without any yellow markings, the suture between upper portion of pleuræ and mesonotum brownish, no distinct surface pollinosity. Abdomen more distinctly shining than thorax, the segments unicolorous black. Legs black, knees brownish; all tarsi yellowish except at apices. Wings clear, veins brown. Squamæ whitish, margins and fringes grayish. Halteres yellow, the knobs white. All bristles black.

Frons nearly half the width of head, orbits distinct, each about half as broad at its broadest part as is center stripe at same part; orbital bristles situated close to inner margin of orbits, five pairs present, the upper pair rather weak, the others becoming successively weaker towards anterior margin, the last (anterior) pair very weak, anterior three pairs incurved; no distinguishable orbital hairs; antennæ rather small, third joint rounded, its surface with white pile; arista rather thick, its length about equal to anterior width of frons, pubescence very short; cheek nearly twice as high as third antennal joint and half as high as eye, marginal hairs weak, vibrissa not well differentiated; height of eye one and a third times its length. Mesonotum with two pairs of very weak dorso-central bristles, the disc covered with rather closely placed hairlike setulæ; scutellar bristles weak, the pairs subequal in length. Abdomen slightly longer than thorax, the segmentation very distinct, surface hairs weak but numerous; hypopygium normal. Legs normal in shape; mid tibiæ without discernible posterior bristles. Wings normal in shape; first costal division more than three fourths as long as second; third vein ending midway between apex of fourth vein and apex of second; fourth ending almost exactly at apex of wing, these three veins distinctly divergent on their last section;

${ }^{1}$ See Ann. Ent. Soc. Amer., Vol. 6, 1913, p. 271. 
inner cross-vein distinctly before end of first vein and two fifths distant from apex of discal cell; outer cross-vein distant about its own length from inner, and very slightly beyond end of first vein; last section of fourth vein about two and a half times as long as the preceding two sections combined; penultimate section of fifth about two thirds as long as last section. Halteres with exceptionally large knob. Length, $2 \mathrm{~mm}$.

Type locality, St. Joseph, Ill., May 17, 1914 (C. A. Hart). Food plant unknown.

This species will "run down" to varifrons Coquillett in the table previously referred to, but may be separated readily by the color of the frons and by the wing venation. In varifrons the black of the frons is not confined to the orbits and ocellar region, but extends over the central stripe, on its upper third at least. The last section of fifth vein of wing in the same species is subequal in length with the preceding section, and the second costal division is nearly twice as long as the first.

Agromyza nigrisquama sp. nov.

Female: Black, subopaque. Wings clear, veins black. Squamæ black-brown, fringes concolorous. Halteres yellow, knobs lemonyellow.

Frons with center stripe opaque, orbits slightly shining, each about one fifth as wide as center stripe, width of frons at vertex slightly over one third the head width, a little narrowed anteriorly, 4 pairs of bristles on orbits, the anterior 2 pairs incurved, the posterior 2 pairs reclinate, orbital hairs sparse; antennæ of moderate size, second joint with distinct dorsal bristle, third joint rounded; arista bare, tapering at base, its entire length equal to from its base to upper orbital bristle; cheek about one sixth the eye height, marginal bristles weak, vibrissæ well differentiated. Mesonotum with 4 pairs of dorso-centrals, the anterior pair in front of suture; no distinct bristles between posterior dorso-centrals; discal setulæ in about 8 irregular rows between anterior dorso-centrals. Abdomen with rather long hairs, especially at apex; ovipositor short, obtuse. Legs slender, the mid tibial setulæ present. Wings broad, costa to end of fourth vein; inner cross vein at distinctly beyond middle of discal cell and slightly before end of first vein; outer cross vein at about its own length from inner; last section of 
fourth vein 6 times as long as penultimate section; veins 3 and 4 gradually divergent on their last sections; last section of fifth vein about one third longer than penultimate section. Length, $2 \mathrm{~mm}$.

Type, Monticello, Ill., June 28, 1914 (J. R. Malloch). Taken by sweeping vegetation on bank of Saugamon River. Food plant unknown.

This species will "run down" to section 34 in the table referred to previously, but may be separated from both of the species therein by the comparative lengths of the last 2 sections of fifth vein as well as other characters. Both isolata Malloch and fragarice Malloch have the last section of the fifth vein shorter than the penultimate section.

\section{A NEW SPECIES OF THRIPOCTENUS (Chalcidoidea). ${ }^{1}$}

\section{By L. T. Williams.}

During an afternoon's collecting in a swampy spot near the Arnold Arboretum, Forest Hills, Mass., a few galls on willow twigs were secured and brought into the laboratory at the Bussey Institution. A casual examination on the date of their collection (July 22, 1915) showed that they contained immature insects of some sort, but no further attention was paid them until August 10, when the galls were opened and found to contain several large black thrips, and a single minute Chalcidoid parasite. Any possible doubt as to the relationship between the insects was removed when the parasite was identified by Professor Brues as belonging to the genus Thripoctenus, which is known to be an enemy of the Thysanoptera.

The genus Thripoctenus was proposed in 1911 by Crawford for a new species from California, belonging to the sub-family Tetrastichinæ, and described by him under the specific name of russelli in honor of its discoverer, the late Mr. H. M. Russell. A second species has recently been described in Europe by Vuillet. I have not had access to this description but the differences in habitat and in the systematic positions of the hosts would indicate that the present species is perfectly distinct. The characters distinguishing it from the type species are well marked, as will be noted later.

1 Contributions from the Entomological Laboratory of the Bussey Institution, Harvard University, No. 112. 

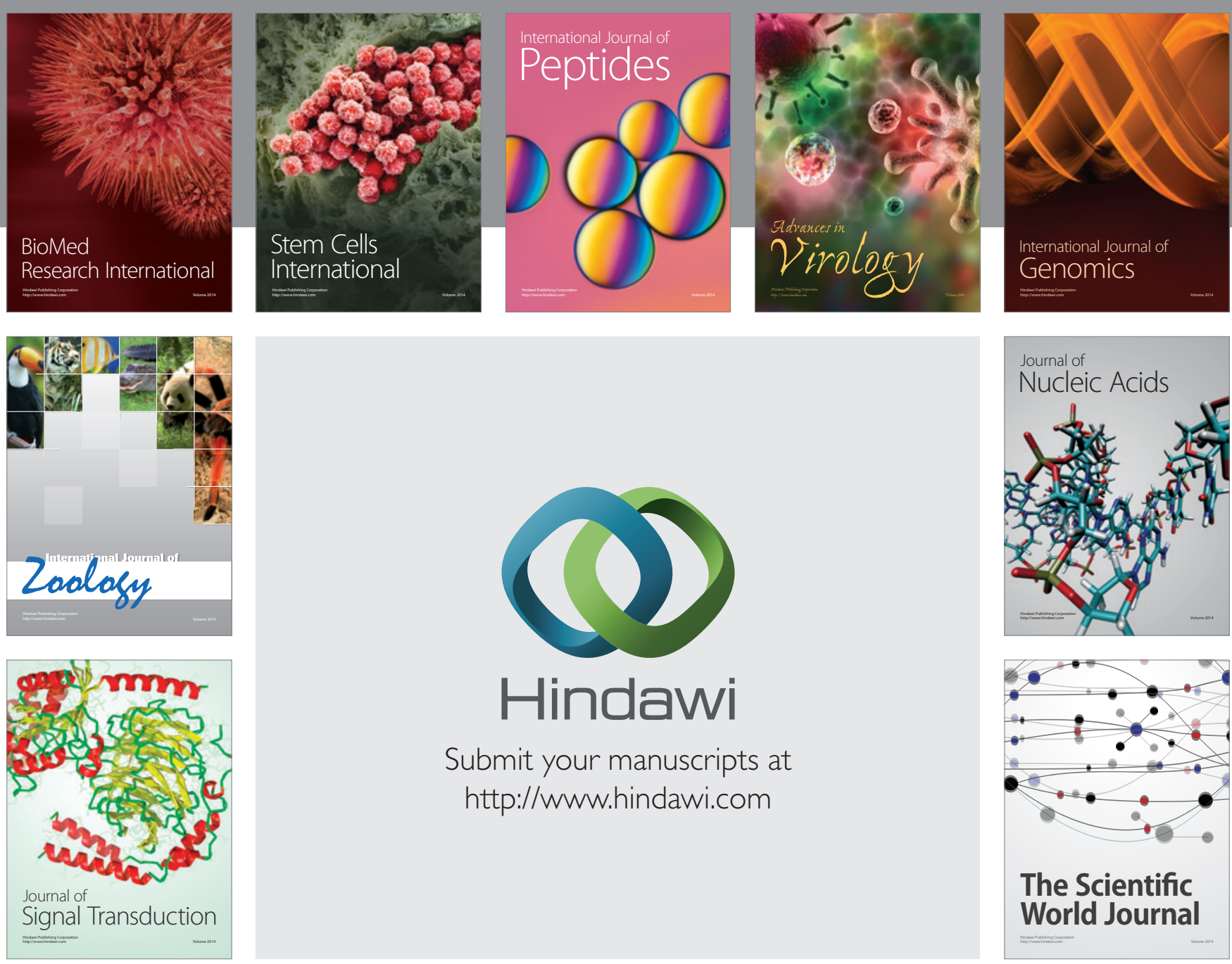

Submit your manuscripts at

http://www.hindawi.com
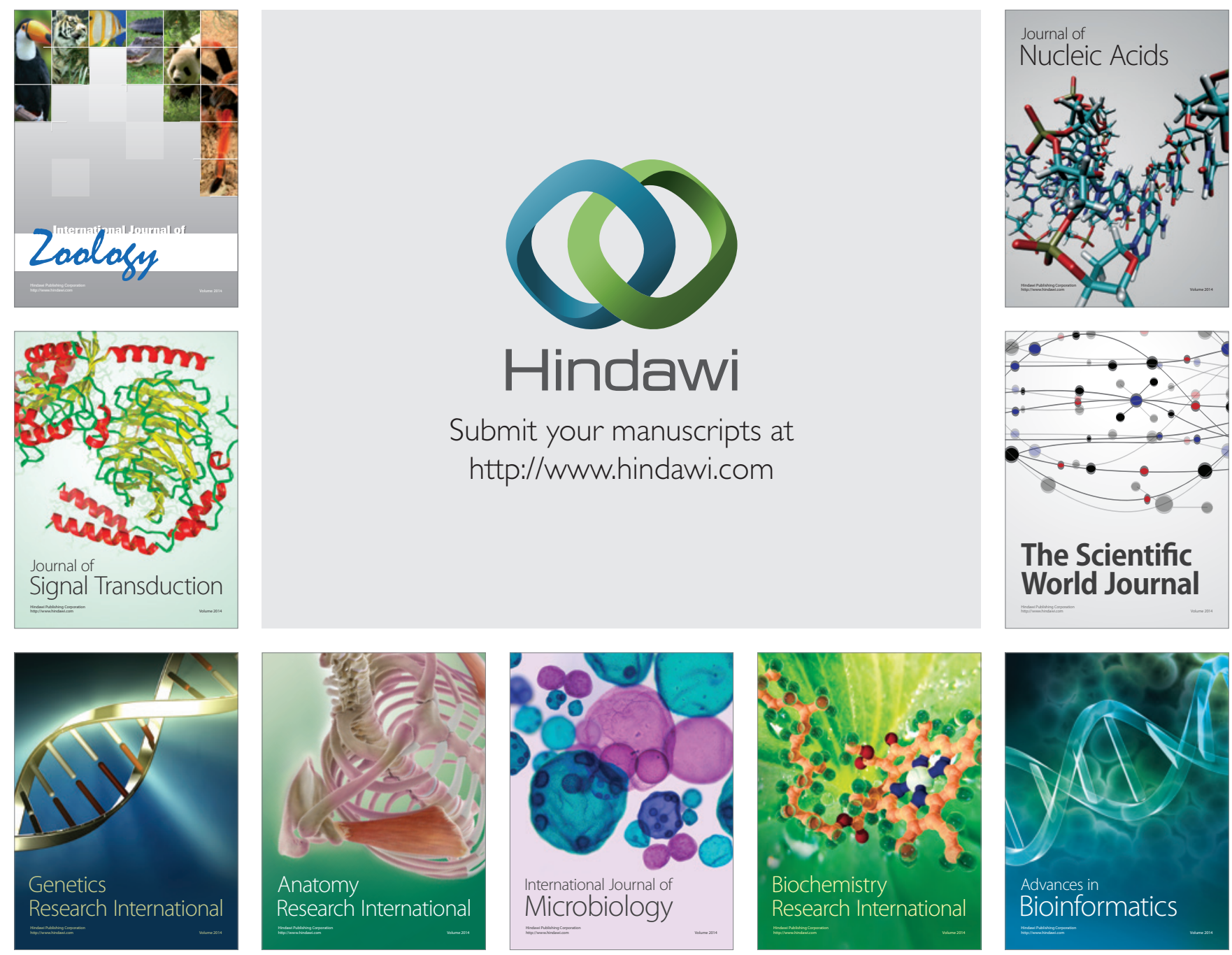

The Scientific World Journal
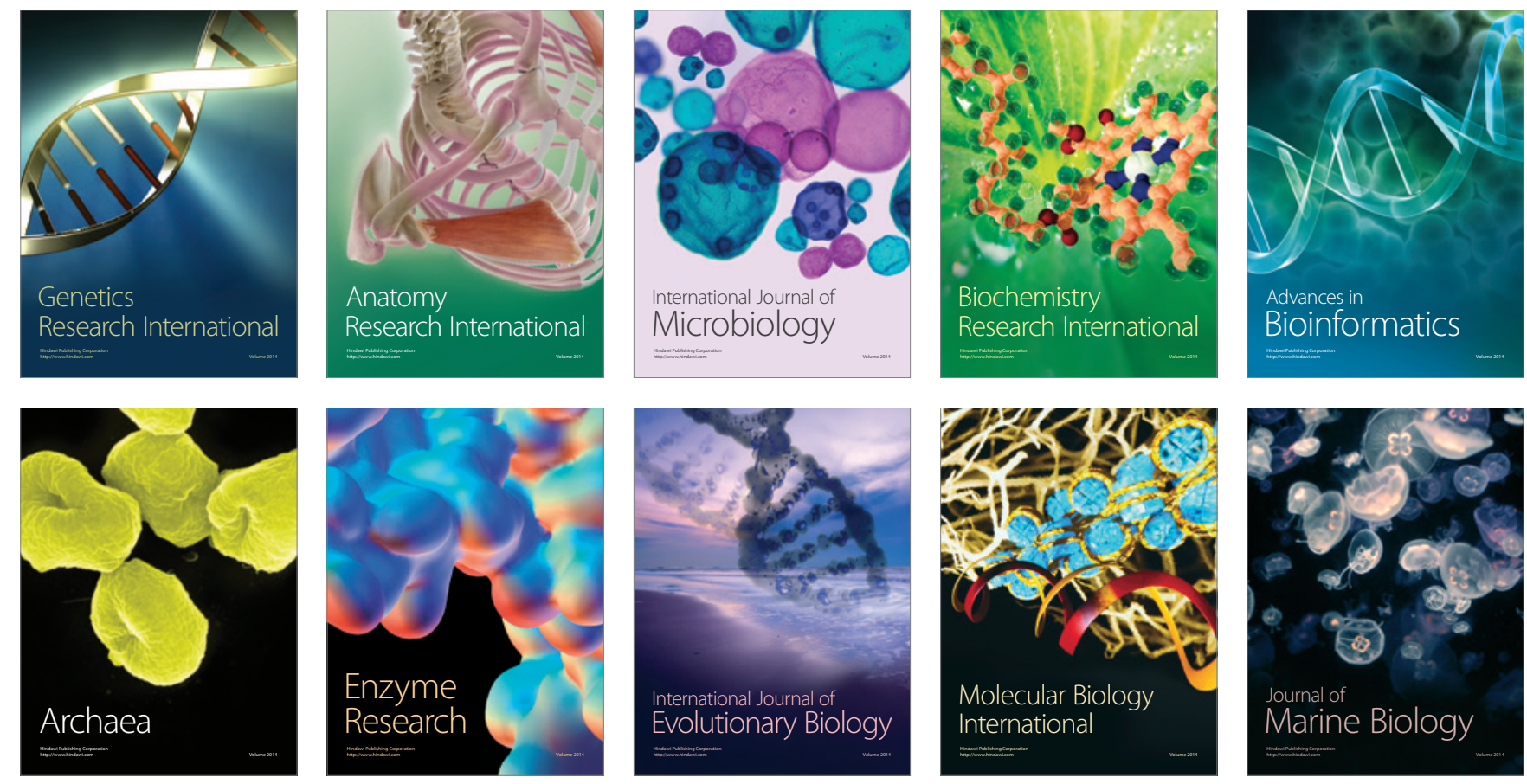